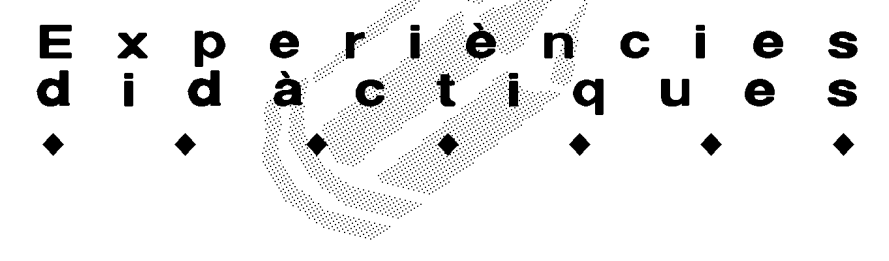

\title{
LA FORMACIÓ DE L'OIENT: UNA TASCA EDUCATIVA EN LA PERSPECTIVA DEL SEGLE XXI
}

\author{
Enriqueta Barniol. Àrea de Didàctica de l'Expressió Musical. URV
}

\section{Escoltar música}

Ens referim a l'acte conscient d'escoltar música, que no s'ha de confondre amb Història de la Música ni amb una activitat passiva. També es fan servir altres termes com: audició, apreciació musical, cultura musical, literatura musical i "història de la música". Escoltar música és la part més difícil, emocionant i arriscada, de l'educació musical; és per mitjà de l'escolta musical que els nens aprenen a gaudir de la música, com un component bàsic per desenvolupar la capacitat del llenguatge musical.

L'home actual pateix un cansament auditiu que és justament advers a la finalitat del goig i del gust artístic. Avui amb l'avenç tecnològic tenim l'oportunitat de poder gaudir d'una quantitat d'obres musicals que mai abans no ens fou possible. En qualsevol moment, podem escoltar les expressions més representatives de la música més antiga fins a les últimes creacions. Però també cal assenyalar com aquest avenç tecnològic s'està convertint en un factor negatiu per al desenvolupament de l'educació i de la cultura. En el cas de la música, veiem com s'estimula el gust pels productes comercials. Tal com deia Kodály (1943), el mal gust és una malaltia real de l'ànima que impedeix el contacte d'aquesta amb les obres mestres, i per tant, amb l'aliment vital que porten dins.

Històricament la preocupació per accedir a la millor comprensió de la música s'inicia en el segle XIX, coincidint amb el desenvolupament de les tendències romàntiques i la democratització de l'art, que permet a la classe dominant accedir als seus béns. Fou a Suïssa que es van organitzar les primeres conferències sobre l'art d'escoltar la música, i es va editar el 1826 un manual per a l'ús dels afeccionats. Alguns anys més tard es va publicar un llibre intitulat "La música al alcance de todo el mundo".

L'escolta es un prerrequisit de totes les altres activitats musicals (Madsen i Madsen, 1978), un procés que implica un entorn actiu de l'oient, i són necessaris l'experiència i l'aprenentatge (Wuytack i Schollaerts, 1973), que engloba la comprensió de la música, desenvolupant-se per mitjà d'una escolta discriminada (Gordon,
1971). Swanwick (1979) afirma que l'audició es la "raó central per a l'existència de la música i el principal objectiu de l'educació musical". En el seu model d'educació musical, l'autor posa l'audició a l'alçada de la composició i de la interpretació, com a activitats essencials per a la pràctica musical. Della Casa (1985) diu: "L'audició és un acte psicològic en el qual participen tant els òrgans sensorials com la intel-ligència. Demana el desenvolupament d'una activitat, i el resultat d'aquesta activitat constitueix un coneixement, és a dir, una apropiació del fenomen sonor que és assimilat i que esdevé, així, representació interior. Diem aleshores que tenim audició efectiva quan, per efecte d'activitats operatives, l'estímul acústic es tradueix en una construcció cognoscitiva, que, segons l'edat i les situacions, podrà emplaçarse a uns nivells més concrets o més abstractes de la intel.ligència". Segons Edgar Willems (1981), la capacitat d'escoltar i de comprendre els diversos missatges sonors i la realitat sonora en tota la seva complexitat i la capacitat de percebre (realitzant operacions com analitzar, reconèixer, descobrir, recordar...) passa pels següents estadis:

- Sentir (sensorialitat auditiva). Com més sensorialment sensibles siguem al so, més descobrirem ja sigui els sons harmònics, les qualitats sonores, etc...

- Entendre (intel-ligència auditiva) o tenir consciència dels seus elements sonors.

- Escoltar (sensibilitat afectiva). Des del punt de vista de l'art, el so pot produir en nosaltres moltes impressions, emocions, sentiments...

- Comprendre que s'ha pres consciència del fenomen sonor. L'hàbit d'escoltar i el desenvolupament de la sensibilitat auditiva no són exclusius de l'educació musical.

L'actitud receptiva i respectuosa que provoca l'audició és un gest que ens ajuda en molts més àmbits de la vida de l'escola. L'obra musical ha de ser vivenciada de forma sensible, racional i comprensiva, permetent al qui escolta ser partícip i involucrant-lo d'alguna manera durant el seu desenvolupament.

Gamble (1984) observa que, essent l'audició "fona- 


\section{E}

mental per a l'experiència musical", generalment es fa servir poc a les escoles. Actualment, però, l'actitud dels professors sembla evolucionar en el sentit de donar major importància a aquesta activitat, tot i que existeix alguna distància entre les intencions i la pràctica pedagògica.

\section{L'escolta musical a l'escola}

Constitueix un espai privilegiat d'emocions. En l'audició de les obres musicals, els nens passen de ser protagonistes de l'activitat a ser-ne exclusivament els receptors, i, en la mesura en què la seva edat i preparació ho permetin, poden rebre les sensacions que l'autor $i$ l'intèrpret han volgut transmetre en les obres. És una experimentació sensorial i natural de tots els elements intrínsecs de la música. S'aprèn a respondre emocionalment $\mathrm{i}$ intel-lectualment a tot allò que ens arriba del món sonor. Es milloren les capacitats auditives i analítiques, diversificant i enriquint els coneixements musicals. És un reforç que es reinverteix a les competències adquirides en les activitats vocals i instrumentals: atenció, sensibilitat, imaginació i memorització. Ajuda a desenvolupar un pensament i un comportament musical, necessaris per a la comprensió i apreciació de la música, una cultura musical, unes competències específiques inherents a la pràctica musical, com la interpretació i la composició, un coneixement dels elements de la música i unes capacitats com la crítica i el sentit estètic. Així doncs, la finalitat de l'audició musical a l'escola és desenvolupar la capacitat d'escoltar, comprendre i analitzar la música (e/ significat-què comunica i l'estructura-com ho comunica).

Assistir a espectacles musicals és, encara avui dia, una activitat minoritària, excepte en aquells casos en què representa un acte social o bé en què se'ns ofereix amb el suport d'un desplegament publicitari de grans proporcions. L'escola ha d'oferir, per tant, aquesta formacio i per això cal que potenciï diverses activitats. Quan un adult va a un concert, a un recital o a l'òpera, normalment no ho decideix els 10 o 15 minuts abans, sinó que ho fa uns dies o fins i tot setmanes abans. I sens dubte, generalment és una ocasió festiva que passa als vespres. Pensem què passa a l'aula. Els alumnes arriben de la classe de matemàtiques 0 de llengua, i al cap de 10 o 15 minuts han d'estar preparats per a escoltar Mozart, Stravinski, el tema de Titànic o el tema de la Família Adams i amb una receptivitat mental i emocional excel-lent. Com podem esperar que 25-30 alumnes vulguin escoltar tots simultàniament la música amb el mateix entusiame, per la nostra conveniència de programar aquella audició?
Aquell que pensa que entén una cosa només llegintne el títol i el programa, s'enganya a si mateix. És necessari també d'ensenyar-los a entendre. Cada ciutadà té dret a conèixer els elements básics de la música $\mathrm{i}$ de poder obtenir la clau amb la qual s'obre el món tancat de la música. Mentre ensenyem els alumnes a escoltar, els estem preparant per a la lliure autonomia quant a escoltar música. L'adquisició d'uns mecanismes psicològics de percepció i, a llarg termini, l'assoliment d'un hàbit d'asistir a concerts, haurien de ser les màximes fites d'aquesta activitat.

\section{Els mecanismes de la percepció musical}

Si prenem el concepte general de percepció com "el tractament de la informació" visual o auditiva, podem considerar l'escolta musical com una activitat de tractament de la informació sonora. Els comportaments perceptius són:

- Detectar. Un estímul sonor.

- Identificar. Comparació entre un estímul sonor i un model arxivat a la memòria. Allò que sentim ha d'estar sempre lligat a allò que hem sentit, tot just, uns instants abans.

- Discriminar. Comparació entre dos esdeveniments sonors, recerca de particularitats que els aproximen o els distingeixen (fet que encara fa intervenir més la memòria i el vocabulari, i suposa una gran capacitat d'abstracció i d'anàlisi).

- Logica. Estructuració del pensament de tal manera que pugui reconèixer la forma i l'estructura.

- Estimació. Lligam entre les capacitats d'associació semàntica i la riquesa de vocabulari; poden ser de naturalesa diversa:

- Apreciacions relatives a l'efecte psicològic o emocional.

- Apreciacions objectives que concerneixen al material sonor, la forma, etc.

- Apreciacions personals que es refereixen a unes normes culturals.

- Apreciacions de significació, que associen la música a un contingut extramusical (associació d'imatges mentals sonores a unes imatges visuals, literàries o a uns sentiments; ex: figuralisme, música descriptiva).

Totes aquestes conductes perceptives s'impliquen dins l'escolta activa. És del tot indispensable ser conscient de la seva gran complexitat a l'hora de construir una progressió pedagògica de l'activitat auditiva. Cal assenyalar també que l'aspecte afectiu és indissociable de l'aspecte cognitiu (el plaer musical, l'emoció estètica estan íntimament lligats a la comprensió del llenguatge musical). 


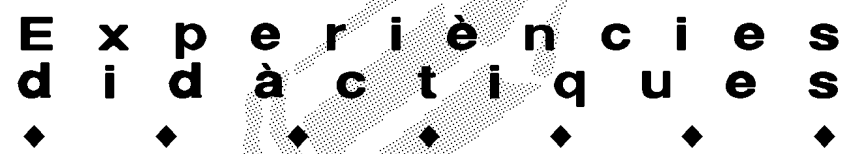

\section{Preparació de la percepció auditivo-musical}

Tant en la percepció com en tota funció psicològica, l'estat de preparació és important i condiciona en part les modalitats d'escolta (activa i passiva) i les reaccions a allò que és percebut. És essencial vetllar per aquest estat de preparació, i particularment tenir en compte les següents situacions:

L'atenció ha d'estar captada i estimulada per tal d'evitar l'escolta passiva. És indispensable un clima de concentració; l'escolta no ha d'estar torbada per esdeveniments sonors i visuals exteriors. Suposa la participació atenta del qui escolta i comporta la capacitat de concentració i anàlisi.

La motivacióés essencial. L'aconseguirem fàcilment informant els alumnes de la proposta de l'audició, viatjant en l'espai i en el temps, i variant les modalitats d'escolta (lligant-ho, per exemple, a una pràctica de llenguatge musical, a un grafisme, a unes imatges, o a un tema abordat en una altra assignatura, etc...).

L'espera es pot crear donant abans de l'escolta consignes que limitin el camp dels paràmetres a identi- ficar, o que centrin l'escolta sobre un element precís a analitzar.

\section{Les modalitats d'escolta}

Escoltar música pot prendre diferents modalitats segons la participació de l'alumne:

a) Escolta passiva; només pel simple plaer d'escoltar, per gaudir i buscar una estimulació interior, o captar l'interès dels nens per l'atracció de la sonoritat o dels ritmes que hi apareixen, sense esperar altra cosa que una resposta visible d'ordre físic (atenció) i afectiu (interès); sempre que es cregui oportú es pot fer una audició de caràcter passiu.

b) Escolta activa, escolta analítica; és la descoberta per mitjà de l'anàlisi (la naturalesa dels alumnes a qui s'adreça ha de portar el mestre a privilegiar una o altra de les escoltes i alternar-les):

- Escolta no guiada; sense cap mena de preparació.

- Escolta guiada oralment amb consignes precises.

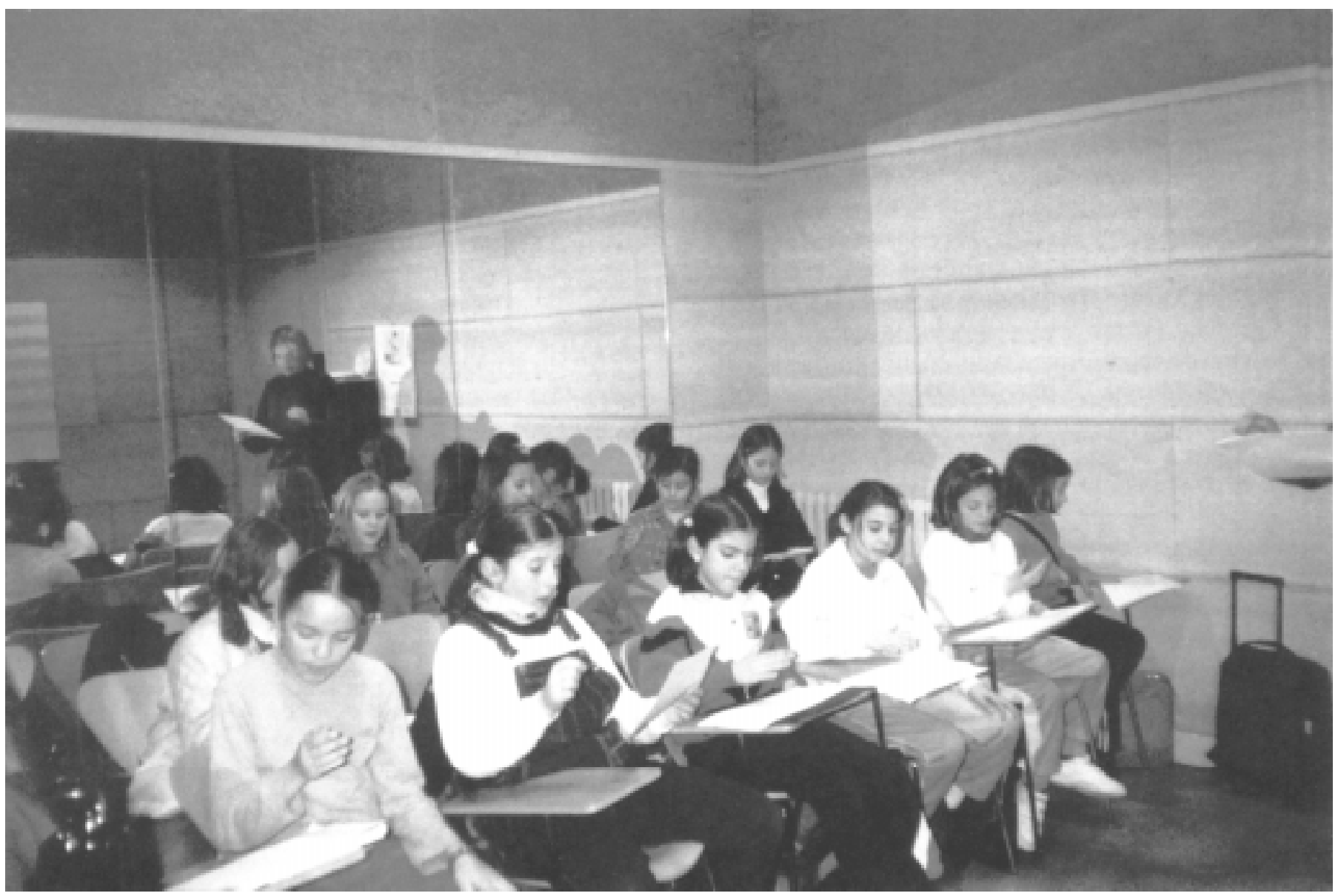




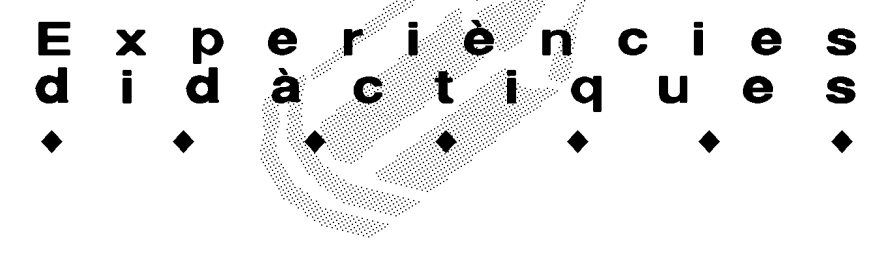

\section{Tipus d'audició}

Seguint la classificació de Barniol (1997), es poden tenir els següents tipus:

Audició enregistrada, (admet la modalitat d'escolta activa i passiva).

Audició viva o en directe, (també admet les dues modalitats d'escolta): conté en la seva essència un element vivencial molt diferent al de l'audició de música enregistrada. És important viure la comunicació que es crea entre l'intèrpret i l'oient dins un vincle de sensibilitat i afectivitat. Per exemple:

- El concert de nadales, el concert de Santa Cecília, el concert de diferents instruments ofert pels nens que van a l'Escola de música o Conservatori, el concert de cant coral de final de curs.

- Els concerts didàctics oferts per diferents entitats. (Joventuts Musicals, concerts familiars de "la Caixa"...). Revesteixen d'un cert ritual pel fet d'anar a concert fora de l'escola.

- Visita a l'escola d'un intèrpret o grup de música.

- Interpretació musical del mateix mestre de música: bé cantant cançons només per fer escoltar, bé tocant amb l'instrument que li és propi. Amb això també els preparem per a les audicions dels artistes professionals. Més val mostrar-los l'autèntic, perquè causa millor experiència als nostres alumnes escoltar el professor que interpreti un minuet de Haydn que no pas escoltar la mateixa obra en un enregistrament.

- Participació al festival musical en la seva comunitat, adoptant un programa conjunt (Trobades de Cant Coral i Grups Instrumentals escolars) i organitzat per Ajuntaments, Consells Comarcals...

Audicions mixtes, per exemple, la cançó cantada pel mestre i després escoltada en un enregistrament interpretada per una coral.

Audició passiva (només admet la modalitat d'escolta passiva): Posar música de fons mentre s'està fent d'altres activitats. Recomanem que la música que "se sent" mentre fan d'altres activitats (plàstica, biblioteca, treball individual, tallers...) hagi estat "escoltada" anteriorment, posant atenció en l'actitud de respecte que anem educant. Més d'un nen, en sentir-la, pot dir: "aquesta música és aquella que ens fan escoltar a...", o potser no dirà res, però la seva mirada serà significativa d'una bona memòria musical i d'un esperit observador.

\section{Didàctica de l'escolta musical}

És fonamental que el mestre/a conegui l'obra (que l'hagi escoltat moltes vegades) i que sigui del seu gust per presentar-la com a audició. Som els primers que hem d'estar convençuts de la bellesa i el profit didàctic de l'obra. És molt important l'actitud del mestre, ja que la seva pròpia vivència de la música influirà en l'ambient que es creï al voltant de l'activitat.

1. Programar un itinerari de fragments/textos musicals definint els objectius específics per a cada seqüència:

En funció de les capacitats audioperceptives dels alumnes i dels seus assoliments:

- Cal fer escoltar músiques molt diverses, portadores de missatges afectius i que comportin una escolta simple i un aprendre a respectar qualsevol tipus de música.

- Cal escollir fragments significatius que per característiques (temàtica, estructura, línia melòdica, tesitura, etc), per estil a conèixer, per estètica abordada... responguin a les característiques $\mathrm{i}$ necessitats de l'activitat a desenvolupar amb els alumnes. L'obra ha de tenir almenys un recurs positiu que sigui fàcilment perceptible i rellevant per al món emotiu del qui escolta.

- Adaptar la durada a la complexitat del fragment i a les capacitats audioperceptives dels alumnes. Així doncs, han de ser curtes i proporcionals als coneixements que els alumnes van adquirint

En funció de la programació d'aula:tenir un repertori de fragments escollits que permetin assolir els objectius que ens proposem:

- Preveure per a cada nivell una llista de continguts a assolir per mitjà de l'escolta i buscant, si s'escau, la coherència amb les altres activitats musicals del curs.

- Preveure un vocabulari lligat al poder emocional de la música a fi de permetre als alumnes d'exprimir la seva subjectivitat.

- Preveure la gestió del temps. L'anàlisi d'un fragment musical pot estar repartit en diverses seqüències, de manera que afavoreixi el joc de la memòria. És convenient d'insistir en la mateixa obra més d'una vegada al llarg del curs per, a poc a poc, anar potenciant la memòria musical mitjançant la repetició i, principalment, d'una banda sentir el goig de tornar a escoltar allò que ja es coneix i que agrada, i de l'altra, verificar, per part $\mathrm{del} / \mathrm{la}$ mestre/a, el grau d'assimilació i de memòria dels alumnes. El fet d'escoltar la mateixa obra al llarg de diverses sessions els permet descobrir, analitzar i anticipar diferents aspectes musicals d'un mateix fragment. Aquesta repetició i el seu treball des de diferents punts de vista va teixint 


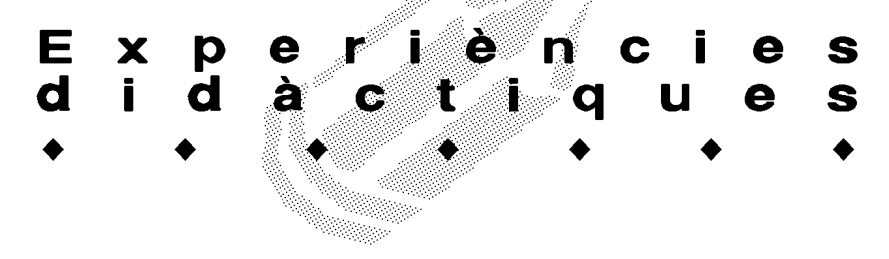

una trama de coneixements i punts de referència que són el motor d'aspectes tan importants com el de seguretat afectiva, la percepció temporal i la vivència artística.

- Preveure les recopilacions escrites ("apunts", mapes conceptuals, esquemes...) que es faran a la pissarra i a la llibreta dels alumnes: aquests han d'escriure al seu quadern narracions sobre els fragments escoltats: vocabulari d'anàlisi, característiques musicals, exemples musicals, trets culturals. Per a cada obra s'elabora progressivament i col-lectivament uns apunts que poden prendre moltes formes combinades: notes escrites, grafisme, fragment de partitura, etc.

- Treballar per temàtica durant algunes setmanes, escollint per exemple "la suite", informant els alumnes d'aquesta forma de treball.

En funció de les possibilitats de treball interdisciplinari, o de les oportunitats que es puguin presentar:

- Emmisió televisiva, animació musical dins el centre, sortida a un concert, etc...

- Buscar sistemàticament per a cada fragment proposat d'altres suports musicals que podrien estarhi en relació.

- Preveure la possibilitat de treballar paral-lelament en altres disciplines.

En funció de la forma com l'escolta serà conduïda (diversificant les formes d'aproximació per estimular la curiositat dels alumnes i escollint la forma més adequada d'abordar el fragment). El/la mestre/a és qui ha de buscar la millor manera de transmetre als nens un fragment musical i buscar aquells elements que facilitin la comunicació, la motivació, la descoberta, per poder-ne fer una valoració. Ha de desenvolupar una sensibilitat que li permeti captar l'estat anímic dels nens per tal de canalitzar-lo.

En funció dels materials i recursos: per dur a terme el treball d'audició cal mantenir i potenciar una infraestructura que impulsi i faciliti la feina del/la mestre/a:

- Escollir els suports pedagògics adaptats: uns documents visuals poden afavorir la percepció dels elements musicals, o l'aproximació a les característiques estètiques: fragment de la partitura (pensem en la utilització d'un retroprojector o la possibilitat de la informàtica) reproducció d'una pintura o d'una escultura, etc...

- Els suports de treball són múltiples: pissarra, document de treball fotocopiat i distribuït per la classe, televisor, ordinador, partitura ampliada...

- Tenir aparells de reproducció adequats. Si l'audició és un element bàsic per a l'educació de l'oïda, no la podem oferir amb uns aparells que facin tota mena de sorolls o que no permetin escoltar la música tal com és.

En funció de les pautes d'avaluació: tota avaluació d'adquisicions lligades a l'activitat d'escolta s'ha de basar sobre l'anàlisi auditiva de documents sonors. Cal avaluar les aptituds (finesa perceptiva, memòria musical) el saber escoltar (identificació, discriminació, dissociació, estructuració en el temps, estimació) i els coneixements (vocabulari i trets culturals). A continuació s'indiquen, a títol orientatiu, un seguit de criteris que es poden fer servir per avaluar el treball realitzat en les sessions d'escoltar música:

- Reconeix i identifica l'audició treballada.

- Recorda els noms dels compositors.

- Reconeix i identifica les repeticions.

- Mostra sensibilitat per l'audició musical i en gaudeix.

- Sap escoltar amb atenció i silenci.

- Distingeix els elements del llenguatge musical treballats en l'audició.

- Reconeix les diferents tècniques de producció de so d'una audició.

- Reconeix, en una audició, els diferents instruments treballats.

2. Estratègies. És un llistat d'estratègies que ens poden orientar per a crear-ne moltes més:

Comparar.

- Les interpretacions d'un mateix fragment musical: en enregistrament i interpretat pels alumnes a classe (cançó, melodia instrumental, basada en la seva línia melòdica principal).

- Un mateix fragment interpretat per diferents músics o bé dirigit per diferents directors per percebre les analogíes i diferències de les diferents versions.

- Amb altres fragments d'un mateix període o de períodes històrics diversos.

Globalitzarl'escolta amb un tema interdisciplinari.

Descobrir i reconèixer diferents aspectes treballats en l'apartat de llenguatge musical:

- Impregnació musical al voltant d'un element característic que sortirà en el fragment.

- Fer notar abans de l'escolta l'element característic que es vol donar a conèixer en el fragment escollit.

- Buscar la forma i estructura del discurs musical amb l'anàlisi fonamentat en els principis d'igualtat, semblança i diversitat.

- Analitzar a la pissarra la partitura del fragment escollit.

Preveure els trets culturals pertinents. Música, context, funció: la música té sempre una funció determinada, 


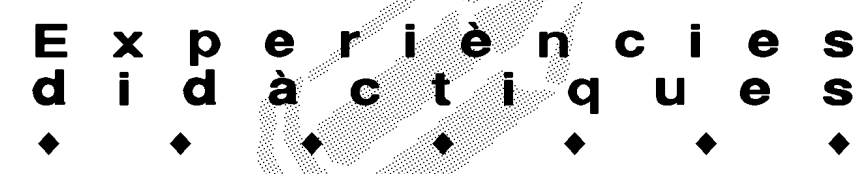

i no podem deixar de prendre en consideració el teixit social en el qual té la seva raó de ser i a partir de la qual manifesta una realitat. Tota música és expressió d'una cultura, entesa tant en sentit històric com geogràfic. En cada ocasió la música comunica per mitjà de les seves estructures uns missatges que poden donar significat a certes situacions, subratllar i posar en evidència missatges comunicats amb altres mitjans, o bé actuar sobre els nostres estats d'ànim. La informació relativa als autors de les obres ha de ser, per als nens i depèn de les edats, breu i a tall d'anècdota, tot explicant algun element que situï els nens i els ajudi a recordar el nom. En els més petits cal tenir present que el concepte d'autor no és gaire clar: per a ells la música la fa qui la interpreta; per tant, s'han d'anar introduint els termes de compositor $\mathrm{i}$ autor cada vegada que es presenta una obra per escoltar, diferenciant-los, si cal, de la tasca de l'intèrpret.

- Familiaritzar els nens amb el nom dels autors, comentar de quin país són i donar referències sobre l'ambient de l'època a través del vestuari, els esdeveniments tècnics i científics, (no tenien televisió, llum elèctrica, cotxes...), etc...

- Situar cada escolta dins el temps, dins l'espai (mapa geogràfic), per visualitzar la música en la seva relació amb totes les activitats humanes.

- Treball personal: petites recerques sobre l'autor, un instrument, un estil musical, revisió de vocabulari, etc.

Delimitarun espai (plafons...) dins l'aula per recollir i potenciar el treball musical que es realitza: penjant una fotografia del músic autor del fragment que s'està treballant, juntament amb la fotografia de la partitura es penja també la de l'instrument que es vol fer destacar en aquell fragment.

Articular l'escolta amb altres formes d'expressió (poesia, cinema, arts plàstiques, llenguatge corporal, narració, etc...).

- II-lustrant un període històric, un estil musical, un aspecte emocional o funcional de la música, etc...

- Anàlisi prèvia d'un text literari o d'una/es imatge/ $\mathrm{s}$, que puguin ambientar prèviament l'escolta.

- Ús de narracions i imatges que expliquin coordinadament la intenció de la composició, etc.

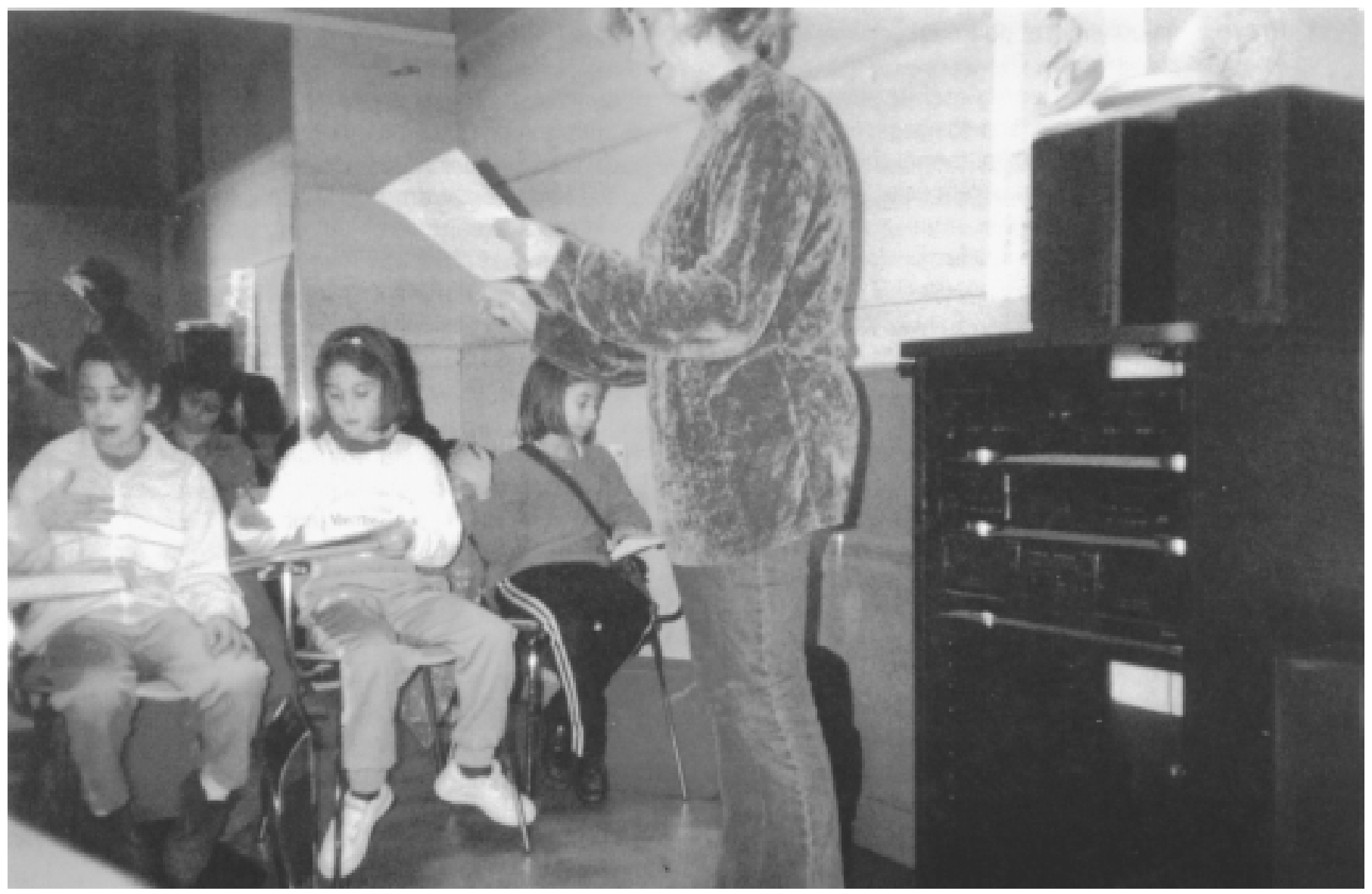




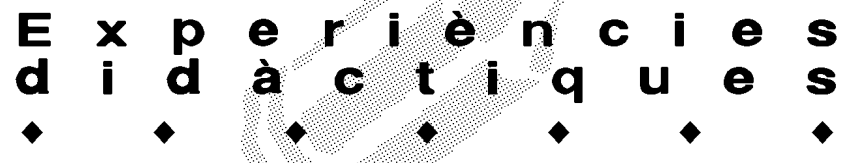

- Respostes a un qüestionari escrit, o en una graella, sobre el que s'ha escoltat.

- Representacions gràfiques a la pissarra,que poden ajudar l'alumne en la seva anàlisi sobre la música treballada, per exemple: a) El musicograma (Wuytack, 1989) on la grafia musical convencional està substituïda per una grafia iconogràfica (línies, colors, ondulacions, granulacions, trames, formes geomètriques o simbòliques, etc) que permeten, d'un sol cop d'ull, la visualització i percepció instantània de l'estructura global de l'obra musical. b) El logicograma: es pot definir com un mitjà gràfic en el qual simultàniament es combinen $i$ interrelacionen dos tipus de grafia: musical (notació convencional) amb no convencional (diagrama del so). Ens servirà principalment per presentar els temes més significatius i que puguin ser cantats o interpretats amb instruments.

- Música i moviment. El moviment permet d'entrar directament en contacte amb la música: expressar de forma física i corporal les emocions suscitades per la música; treballarem les frases musicals que configuren el fragment prenent consciència de la respiració, que ens ajudarà a trobar el moviment adequat de les frases musicals; incidirem en els aspectes més rellevants del fragment musical tenint en compte els accents, les pulsacions i els ritmes, i vivenciant-los amb el cos, tot respectant i valorant el caràcter corporal de cada nen; el fet d'haver d'expressar una música amb moviment facilita que la puguem sentir millor per dins que quan l'escoltem des del repòs. Per exemple: les improvisacions, tant individuals com col-lectives, desenvolupen i afavoreixen el llenguatge corporal propi de cada nen. Tots els moviments els possibilitarem dins l'espai en diferents figures (rotllanes, fileres). Dramatitzacions sobre el contingut semàntic que engloba. Expressions músico-corporals que destaquin les qualitats rítmico-melòdiques i l'estructura del fragment escoltat.

Altres: són interessants les audicions dels autoenregistrements, ja que els nens escolten el que canten 0 interpreten amb instruments, i desenvolupen així un esperit observador rítmic, melòdic, harmònic i formal de la seva pròpia tasca.

\section{Metodologia.}

Hi ha un element previ, i al mateix temps paral-lel, molt important que cal tenir en compte i treballar: el silenci.
Primera escolta. Una primera escolta privilegiarà la sensibilitat i la imaginació portant-nos a la globalització dels esdeveniments sonors. La primera escolta suposa un estat de disponibilitat que exclou tota altra activitat $i$ porta l'alumne a impregnar-se del clima de l'obra sense inquietar-se prematurament a causa de l'anàlisi o de la identificació, i contribueix al plaer d'escoltar sense tenir la necessitat de fer cap treball posterior. Es pot fer un comentari previ a l'audició que estimuli l'interès, però que no interposi gaires consideracions entre els nens $i$ la música, ja que és millor que siguin ells els qui la vagin descobrint. Un cop feta aquesta primera escolta, invitem els alumnes a expressar-se de forma sensible en diferents formes (verbalment, gestualment, amb moviment corporal, per mitjà d'imatges, per mitjà del dibuix o de grafisme, induïts prèviament per una consigna inicial). Cal promoure el diàleg-comentari sobre el que s'ha escoltat, per tal que els alumnes aprenguin a expressar les pròpies vivències, els seus sentiments i les seves opinions. Són insuficients els comentaris "m'agrada" o "no m'agrada", convé que de mica en mica puguin explicar-se amb més concreció. La conjunció d'aquestes percepcions individuals condueix a una apreciació global i col-lectiva, primer gran pas dins la descoberta del sentit artístic de l'obra: a) per inducció guiada: proposarem oralment o per escrit uns adjectius entre els quals es pot escollir; b) per inducció lliure: els nens busquen lliurement els que consideren més apropiats (que obliga a un treball de recerca i de reflexió molt més aprofundit).

Escoltes següents. Les escoltes següents portaran l'alumne a descobrir, per després apropiarse dels elements musicals tècnics i culturals explicats pel professor. Conduirem els alumnes a memoritzar i reproduir les cèlules, els motius, les frases, temes, etc., a redescobrirlos dins l'obra treballada, i després dins l'audició d'altres fragments rellevants d'estètiques eventualment diferents.

\section{Problemes relacionats amb aquest tipus d'activitat}

En altres assignatures, quan un alumne no assisteix a classe es recupera bé amb alguns consells del professor, bé demanant apunts a un company bé estudiant en un llibre de text... Malauradament, aquestes solucions serveixen de ben poc en el nostre cas, perquè, com pot, l'alumne que no ha assistit, escoltar els exemples que el grup ha escoltat de forma col-lectiva i amb la mateixa vivència? Tinguem en compte que en molts alumnes les seves audicions es redueixen a las de classe. Tot això ens fa pensar a buscar solucions com ara: a) Encarregar a alguna empresa la gravació de cintes a preu econòmic amb tots els exemples d'escolta, 


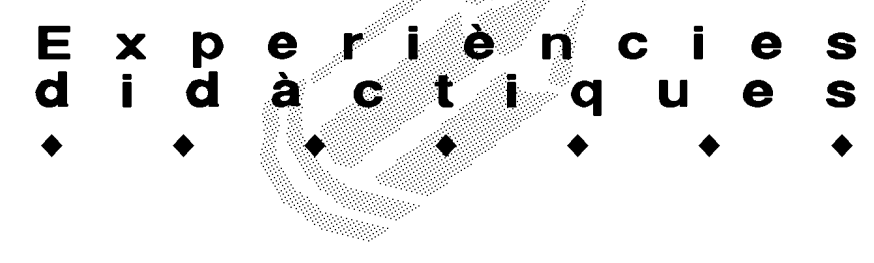

que després els nens compraran com fan amb els llibres de text. b) Confeccionar una fonoteca (crear un fons de cintes de préstec per a cada grup de classe que ens permeti traslladar el treball musical iniciat a l'escola, i potenciar la seva continuïtat dins l'àmbit familiar).

També cal esmentar que és més fàcil i simple ensenyar una cançó nova, que no requereix un esforç especial a un professor de música ben capacitat; que no pas fer escoltar música, que necessita molta més energia en preparació i ensenyament, ja que requereix una major atenció i cura per part d'ambdós: professor i alumne.

\section{Finalment}

Els qui ens dediquem a l'ensenyament de la música hem de ser conscients de la nostra gran responsabilitat en aquests temps de canvis i renovades exigències a l'entrada del nou mil-lenni. Hem de preparar els alumnes perquè puguin ser autònoms en la seva vida musical. Una experiència musical donada en el seu moment precís pot aportar tal influència emocional a una generació jove que pot ser determinant per a tota la seva vida. L'escolta musical pot ser el punt de partida, perquè posteriorment i de manera sistematitzada els nens s'apropin al fenomen musical d'una manera receptiva $i$ com una font més d'estudi i enriquiment de la seva vida.

Per altra banda, també caldria persuadir els nostres compositors que escrivissin més obres destinades a l'educació musical, incloent-hi els contes musicals per a nens. I sol-licitar als professionals de la indústria musical que comparteixin la seva experiència amb els nostres alumnes.

És important considerar la influència dels llibres de text, editats generalment amb l'acompanyament d'un $\mathrm{CD}$, amb audicions preparades, que són un recurs molt fàcil d'usar i de preparació a l'aula, però que condicionen inevitablement la selecció del repertori i limiten el desenvolupament d'una actitud de recerca del mestre. Per tant, és necessari que els programes de Formació Inicial proporcionin als futurs mestres aquest desenvolupament d'aquesta actitud de recerca, que els permeti una contínua reflexió i reformulació de la pràctica pedagògica, i en els programes de Formació Permanent una actualització regular sobre diverses metodologies d'anàlisi i recerca d'audició musical.

En les meves classes de música a l'escola, sovint escoltem música. Interpretem concerts. A vegades vénen amics a fer-nos audicions. I també sortim de tant en tant a la ciutat per assistir a algun concert. De tot això em queda molt endins el silenci amb què els nens miren els músics. Un silenci prenyat de sensibilitat. El silenci d'estar atent a quelcom que allà es crea. És clar que els nens van preparats a totes aquestes situacions. En parlem a classe. I tenim molt clar que tot el que és nou moltes vegades no agrada. Sabem que per a la música cal un esforç. Unes ganes d'apropar-s'hi. Nens que al cap dels anys he trobat en concerts ciutadans de tot tipus. Que tenen a casa la seva petita discoteca, que els agrada Bach, Mahler, el jazz i bon rock. Que a vegades canten en una coral i que impregnen els seus fills d'aquesta apreciació musical. Han après a escoltar la música com llegir un llibre, veure una pel.lícula, fer una fotografia o visitar una galeria d'art. Demostrem als nostres alumnes que escoltar música és una activitat agradable.

\section{Referències bibliogràfiques}

BARNIOL, E. Didàctica de l'Expressió Musical. Edició del Servei Lingüístic de la Universitat Rovira i Virgili. Tarragona. 1997. Pàg. 44-48.

DELLA CASA, M. Educazione musicale e curricolo. Edit. Zanichelli. Bolonya. 1995.

GAMBLE, T. Imagination and Understanding in the Music Curriculum. «British Journal of Music Education», 1, 1 (1984) 7-25.

GORDON, E. The Psychology of Music Teaching. New Jersey: Prentice Hall, Inc. 1971.

KODÁLY, Z. Visszatekintés /. Ed. Corvina. Budapest. 1943. Pàg. 133.

MADSEN, C.K. i MADSEN, C.H. Investigación Experimental en Música. (Trad. A. L. Frega) Ediciones Marymar. Buenos Aires. 1978.

SWANWICK, K. A basis for Music Education. NFER/ Nelson. London. 1979.

SWANWICK, K. Some Observations on Research and Music Education. «British Journal of Music Education». 1, 3 (1984) 195-203.

WILLEMS, E. El valor humano de la educación Musical. Edit. Paidós. Barcelona.1981.

WUYTACK, J. i SCHOLLAERT, P. Aktief Muziek Beluisteren. Ed. De Monte. Leuven. 1973.

WUYTACK, J. L'audition musicale active par le musicogramme. «Musique et Culture». Strasbourg. 62 (1995). 